\title{
FAKTOR - FAKTOR YANG MEMPENGARUHI PASIEN FRAKTUR MEMILIH PENGOBATAN TRADISIONAL
}

\author{
Yosephina Maria Hawa Keytimu \\ Universitas Nusa Nipa \\ fienkeytimu@gmail.com
}

\begin{abstract}
The selection of traditional medicine treatment still be a choice in Indonesia. One of the most famous traditional medicine treatment is traditional bone setters. Traditional medicine treatment still used in the society is not about the lack of health service facility, but there are some factors that drive to determine the methode of medical treatment. The study aims to analize the factors influencing clients with bone fracture in the selection of traditional bone setters. This research use quantitative approach with a cross sectional study. The population in this study was 30 clients with bone fracture who choose traditional bone setters than medical treatment, and used total sampling. In this study used questionnaries measuring instrument on June-Juli 2021. Data are analized step by step including univariate anlysis, bivariate analysis by using chi-square test with significant level $75 \%(a<0,25)$, and multivariate analysis by logistic regression. The results based on chi square analysis get each of the variable, the $p$ value with education $(0,01)$ knowledge $(0,341)$ economy $(0,126)$ family support $(0,850)$. The results based on multivariate analysis by logistic regression there are significant value, education 0,016<0,25 and economy 0,097<0,25. From the results of the Key Research that there is an influence of educational and economic factors on the choice of traditional fracture treatment.
\end{abstract}

Keyword : Education, knowledge, economy, family support, traditional bone setters

\begin{abstract}
ABSTRAK
Pemilihan pengobatan tradisional masih menjadi salah satu pilihan dalam pengobatan masyarakat di Indonesia. Pelayanan kesehatan tradisional yang cukup populer di masyarakat Indonesia adalah pengobatan fraktur atau sering disebut masyarakat sebagai dukun patah tulang. Pengobatan tradisional masih digunakan oleh sebagian besar masyarakat bukan hanya karena kekurangan fasilitas pelayanan kesehatan formal yang terjangkau, melainkan lebih disebabkan oleh banyak faktor. Tujuan dari Penelitian ini adalah untuk menganalisis faktor-faktor yang mempengaruhi pasien fraktur memilih pengobatan tradisional. Jenis Penelitian ini adalah Penelitian kuantitatif dengan desain crossectional. Populasi dalam Penelitian ini adalah semua pasien fraktur yang menolak tindakan medis dan memilih untuk berobat ke pengobatan tradisional/dukun patah tulang dengan jumlah sampel 30 orang, yang diperoleh dari total sampling. Data yang digunakan adalah data primer yang diambil dengan menggunakan kuesioner yang dilaksanakan pada bulan Juni-Juli 2021. Analisis data menggunakan analisis univariat dan analisis bivariat menggunakan uji chi square dengan tingkat kemagnaan $75 \%(\alpha<0,25)$ sedangkan analisis multivariate menggunakan uji regresi logistik. Hasil Penelitian berdasarkan uji chi square didapatkan nilai variable pendidikan $p$ value 0,01 , pengetahuan 0,341 , ekonomi 0,126 dan dukungan keluarga 0,850. Hasil analisis multivariate dengan uji regresi logistic didapatkan nilai signifikan pada variable pendidikan yaitu $0.016<0,25$ dan 0,097<0,25 pada variabel ekonomi. Dari hasil Penelitian disimpulkan bahwa terdapat pengaruh faktor pendidikan, dan ekonomi terhadap pemilihan pengobatan tradisional fraktur.
\end{abstract}


Kata Kunci : Pendidikan, Pengetahuan, Ekonomi, Dukungan Keluarga, Fraktur

Pengobatan Tradisional

\section{PENDAHULUAN}

Tuntutan akan pelayanan kesehatan selalu berkembang seiring dengan perkembangan zaman dan ilmu kesehatan, peralatan semakin maju, sumber daya manusia dan sistem pelayanan pengobatan yang semakin berkembang. Tidak hanya di rumah sakit, tetapi juga munculnya layanan kesehatan seperti klinik, puskesmas, posyandu, poskesdes, dan posbindu yang juga menjadi pilihan tempat berobat. Selain itu, pilihan pengobatan tradisional telah menjadi salah satu pilihan pengobatan masyarakat Indonesia (Kementerian Kesehatan, 2018)

Organisasi Kesehatan Dunia (WHO) mulai mengembangkan pengobatan tradisional pada tahun 2002 karena dianggap penting dalam sistem kesehatan, khususnya dalam pengobatan tradisional. Pilihan pengobatan tradisional di Amerika menunjukkan bahwa $23 \%$ pasien dengan masalah muskuloskeletal lebih memilih pengobatan tradisional (A.Graham Apley; Louis Solomon, 1995)

Menurut hasil Riset Kesehatan Dasar (Riskesdas) Badan Penelitian dan Pengembangan Kementerian Kesehatan RI pada tahun 2013, telah terjadi kasus patah tulang akibat cedera antara lain jatuh, kecelakaan lalu lintas dan trauma tumpul atau tumpul di Indonesia. Luka akibat jatuh sebanyak 45.987 kasus dan 1.775 orang (3,8\%), dari 20.829 kasus kecelakaan lalu lintas, 1.770 orang $(8,5 \%), 14.127$ trauma akut/tumpul mengalami patah tulang, diantaranya 236 orang $(1,7 \%)$. Data kasus patah tulang di NTT diperoleh 5,8\%, terjadi karena kecelakaan, trauma tajam/tumpul dan kelainan patologis tulang.
Data Kasus Fraktur di RSUD dr. T. C. Hillers Maumere pada tahun 2019 sejumlah 436 kasus dan tahun 2020 sejumlah 384 kasus. Dari 820 kasus tersebut, 718 orang $(87,56 \%)$ adalah kasus baru dan 102 orang $(12,43 \%)$ adalah kasus fraktur dimana pasien datang sudah lebih dari satu minggu setelah kecelakaan atau terjadinya fraktur. Data kasus faktur pada bulan Januari - April 2021 tercatat 58 kasus. (RSUD dr. T.C. Hillers, 2020). Berdasarkan data dari register ruang Dahlia dan UGD RSUD dr. T.C.Hillers Maumere pada bulan Januari - Juni 2021, tercatat 32 kasus fraktur pulang paksa dimana pasien menolak melakukan pengobatan di RSUD dr. T. C. Hillers Maumere dan memilih untuk berobat ke dukun atau pengobatan tradisional.

Dari hasil wawancara sebagian besar klien mengatakan alasan mereka yaitu karena faktor ekonomi. Mereka mengatakan tidak mempunyai biaya untuk membayar perawatan di rumah sakit. Adapun yang mengatakan jika ke dukun pembayarannya dapat dicicil atau dapat berupa barang. Ada beberapa factor yang menyebabkan pasien fraktur lebih memilih pengobatan tradisional diantaranya pengetahuan, pendidikan, ekonomi dan dukungan keluarga. Menurut (Worku et al., 2019) bahwa beberapa pasien yang memiliki pengetahuan yang kurang lebih memilih pengobatan tradisional karena mereka beranggapan bahwa pengobatan tradisional untuk pasien fraktur hampir sama dengan pengobatan di rumah sakit yang menggunaakan peralatan yang modern. Pasien fraktur tersebut disinyalir kurang mendapat edukasi atau penyuluhan kesehatan tentang majamen cedera tulang. Hal ini sejalan dengan penelitian oleh (Lee et al., 2004) yang melakukan penelitian di Jepang. Mereka menemukan bahwa pasien fraktur dengan pendidikan yang rendah 
lebih memilih pengobatan tradisional dibandingkan pasien dengan tingkat pendidikan yang lebh tinggi. Pasien fraktur mencari alternative pengobatan tradisional karena mereka tidak puas dalam beberapa hal terkait pengobatan konvensional

Perasaan tidak puas ini terkait dengan biaya perawatan dan waktu tunggu yang lebih lama dibandingkan pengobatan tradisional. Faktor ekonomi juga mempunyai peranan besar dalam penerimaan atau penolakan suatu pengobatan. Faktor ini diperkuat dengan persepsi masyarakat bahwa pengobatan alternatif membutuhkan sedikit tenaga, biaya dan waktu Hal ini menjadi alasan klasik pasien fraktur lebih memilih pengobatan tradisional di rumah dari pada harus dirawat di rumah sakit. Para pasien tersebut tidak menyadari bahaya melakukan pengobatan tradisional tentang efek samping pengobatan alternative terutama toksisitas jangka panjang (Mattarneh, 2015) Alasan lain yang didapatkan yaitu tidak adanya dukungan dari keluarga, dimana semua keputusan untuk memilih pengobatan selalu dirundingkan terlebih dahulu dengan keluarga besar. (Diviani et al., 2020)

Tujuan penelitian ini adalah untuk mengetahui factor-faktor yang mempengaruhi pasien fraktur memilih pengobatan tradisional.

\section{METODE}

Penelitan ini menggunakan rancangan penelitian kuantitatif dengan desain penelitian cross sectional dimana pengumpulan data pengukuran variabel independen dan variabel dependen dilakukan pada waktu yang bersamaan.

Populasi pada penelitian ini adalah semua pasien fraktur di RSUD dr.T. C. Hillers Maumere yang menolak tindakan medis dan memilih untuk berobat ke dukun atau

pengobatan tradisional berjumlah 32 orang. Teknik pengambilan sampel yang digunakan dalam penelitian ini adalah dengan menggunakan total sampling/sampling jenuh

Variabel yang diteliti dalam penelitian ini terdiri dari variabel independen dan variable dependen. Yang menjadi variable independen (faktor pendidikan, pengetahuan, ekonomi dan dukungan keluarga) sedangkan variable independen (pengobatan tradisional pasien fraktur).

Instrument yang digunakan dalam penelitian ini menggunakan kuesioner yang sudah dilakukan uji validitas dan reliabilitas dengan nilai Cronbach's Alpha 0,922 dan nilai reliabilitasnya yaitu 0,60

\section{HASIL}

Karakteristik responden berdasarkan jenis kelamin

\begin{tabular}{|c|c|}
\hline $\begin{array}{l}\text { Tabel } 1 \\
\text { berdasarkan } \\
\text { pekerjaan }\end{array}$ & \begin{tabular}{ccr}
\multicolumn{2}{c}{ Distribusi } & responden \\
jenis kelamin dan
\end{tabular} \\
\hline Jenis kelamin & $\begin{array}{l}\text { Frekuensi } \\
\text { (f) }\end{array}$ \\
\hline Laki - Laki & 20 \\
\hline Perempuan & 33,3 \\
\hline \multicolumn{2}{|l|}{ Pekerjaan } \\
\hline IRT & 6,7 \\
\hline Petani & 36,7 \\
\hline $\begin{array}{l}\text { Wiraswasta/ } \\
\text { pedagang }\end{array}$ & 6,7 \\
\hline Karyawan & 6,7 \\
\hline Lain-lain & 43,3 \\
\hline Total & 100 \\
\hline $\begin{array}{l}\text { Berdasarka } \\
\text { menunjukkan b } \\
\text { paling banyak } \\
\text { dibandingkan } \\
\text { perempuan, } \\
\text { berdasarkan pek } \\
\text { lain-lain }\end{array}$ & $\begin{array}{l}\text { an tabel di atas } \\
\text { oahwa dari } 30 \text { responden } \\
\text { berjenis kelamin laki-laki } \\
\text { yang berjenis kelamin } \\
\text { sedangkan karakteristik } \\
\text { erjaan yang terbanyak yaitu }\end{array}$ \\
\hline
\end{tabular}

Tabel 1 Distribusi responden berdasarkan jenis kelamin dan pekerjaan 
Berdasarkan tabel 3 didapatkan bahwa factor pendidikan dan ekonomi mempunyai pengaruh terhadap pemilihan pengobatan tradisional sedangkan factor pengetahuan dan dukungan keluarga tidak memiliki pengaruh terhadap pemilihan pengobatan tradisional oleh pasien fraktur

Tabel 3 Faktor-Faktor Yang Mempengaruhi Pasien Fraktur Memilih Pengobatan Tradisional

\begin{tabular}{llccl}
\hline Variabel & $\mathbf{N}$ & $\boldsymbol{\alpha}$ & $\mathbf{C I}$ & p value \\
\hline Pendidikan & 30 & 0,25 & $1,31(0,65-1,98)$ & 0,01 \\
\hline Pengetahuan & 30 & 0,25 & $0,19(-0,43-0,83)$ & 0,341 \\
\hline Ekonomi & 30 & 0,25 & $1,94(0,51-3,57)$ & 0,126 \\
\hline $\begin{array}{l}\text { Dukungan } \\
\text { keluarga }\end{array}$ & 30 & 0,25 & $-0,6(-2,05-0,86)$ & 0,850 \\
\hline
\end{tabular}

\section{PEMBAHASAN}

Pendidikan memiliki pengaruh yang besar terhadap keputusan seseorang dalam menentukan tempat pelayanan pengobatan dikarenakan semakin tinggi pendidikan seseorang maka seseorang akan lebih mudah untuk mengakses dan menangkap informasi. Hal ini sejalan dengan penelitian yang dilakukan oleh Wulandari dkk, 2017 tentang Faktor-faktor yang berhubungan dengan penggunaan obat tradisional menunjukkan bahwa ada hubungan antara tingkat pendidikan dengan penggunaan obat tradisional

Sejalan dengan teori tersebut, penelitian yang dilakukan oleh (Liang et al., 2018) mengatakan bahwa dengan pendidikan yang baik yang dimiliki oleh seorang pasien, akan menunjukkan manfaat yang potensial dan positif pada saat memutuskan melakukan pengobatan. Manfaat tersebut berdampak pada status kesehatan dari pasien tersebut. pasien dengan tingkat pendidikan tinggi lebih mungkin untuk memiliki kesehatan yang lebih baik dan pengetahuan tentang kondisi penyakit dengan demikian mereka cenderung lebih rentan terhadap kecemasan, depresi, dan emosi negatif lainnya yang disebabkan oleh kesalahan dan berita negatif daripada mereka yang berpendidikan rendah; dengan demikian, mereka dapat secara aktif menanggapi dan secara positif menghadapi kesulitan di depan mereka (Xiao et al., 2020)

Berbeda dengan factor pendidikan, pada factor pengetahuan terlihat bahwa tidak ada pengaruh terhadap pemilihan pengobatan pasien. Menurut peneliti hal ini mungkin saja terkait dengan perbedaan dalam budaya pasien fraktur. Budaya atau kebiasaan yang lahir dari dalam individu itu sendiri memainkan peranan penting terhadap pemilihan pengobatan. Orang dengan kepribadian introvert mengalami tantangan berkomunikasi dengan dunia luar; dengan demikian, mereka kurang mendapat perhatian dan dukungan dari orang lain dan lebih rentan terhadap mental pasca gangguan trauma setelah stimulasi stres dibandingkan dengan orang yang mempunyai kepribadian ekstrovert.

Menurut (R. Bassey, Aquaisua N. Aquaisua, 2009), seseorang memiliki faktor internal dimana motivasi, persepsi, sikap, gaya hidup, kepribadian dan belajar terkandung didalamnya. Point-point didalam faktor internal inilah yang berpengaruh terhadap perilaku seseorang melihat dan mempelajari sesuatu yang ada didepan mata sesuai dengan pengalamannya.

(Agoes, 1996) mengungkapkan bahwa manusia memiliki mata, telinga atau pikiran yang membantunya dalam memilih suatu tindakan. Dari hasil diatas peneliti berasumsi bahwa dalam mengambil keputusan untuk menjalani pengobatan tradisional walaupun rata-rata responden mempunyai pengetahuan baik namun keputusan pemilihan pengobatan tradisional didapat dari pengalamanpengalaman salah satu anggota keluarga 
atau kerabat, juga adanya dorongan atau sugesti dari dalam diri yang meyakini bahwa pengobatan tradisional lebih baik dan lebih cepat penyembuhan dibanding dengan pengobatan medis yang harus memerlukan waktu yang lama.

Hal yang sama dikemukakan (Foroudi et al., 2021) menyatakan bahwa adanya stock of knowledge dalam diri setiap orang menjadi kerangka acuan untuk menafsirkan berbagai peristiwa yang dihadapinya dalam kehidupan sehari- hari. Pengetahuan ini diperoleh individu dari proses belajar bukan berasal dari kelahiran. Sebagian isi pengetahuan yang dimiliki individu didapatkannya melalui pengalamannya sendiri dan sebagian yang lain didapatkannya dengan mereka yang menjalani kehidupan bersama. Bahkan keyakinan akan sesuatu yang lebih berkuasa dari dirinya pun tak luput dari salah satu yang mendorongnya mengambil keputusan. Dalam hal memilih suatu pengobatan terkait patah tulang, faktor paling utama yang dilihat adalah keuntungan apa yang akan didapatkan dari pengobatan tersebut dan biaya yang dibutuhkan selama pengobatan. (Kurnia, 2019) dalam penelitian tentang pengobatan tradisional fraktur di Sumedang, ditemukan bahwa individu memilih berobat ke pengobatan tradisional fraktur karena adanya alasan ataupun anggapan bahwa pengobatan tradisional fraktur dapat memberikan kesembuhan lebih cepat dengan biaya yang dibutuhkan relatif lebih murah dari pada biaya perawatan di rumah sakit.

Dari hasil penelitian, peneliti berpendapat bahwa faktor ekonomi juga sangat mempengaruhi pemilihan pengobatan tradisional dikarenakan biaya pengobatan di rumah sakit yang relatif mahal dan rata-rata responden dengan tingkat ekonomi rendah. Jika pasien tidak memiliki jaminan kesehatan maka akan kesulitan dalam membiayai perawatan di rumah sakit. Masyarakat modern dengan tingkat ekonomi yang tinggi akan memilih dokter atau fasilitas kesehatan untuk mengatasi penyakitnya.

Sebaliknya masyarakat yang kurang mampu langkah pertama yang diambil untuk mengobati penyakitnya dengan membuat obat sendiri dari pengetahuan tradisional turun-temurun atau mencari pengobatan alternatif yang diyakini bisa menyembuhkan penyakitnya (Peprah et al., 2018)

Setelah kecelakaan traumatis, orang dengan pendapatan rendah bias jadi mengalami peningkatan psikologis dan kesulitan fungsional karena keterbatasan sumber daya pekerjaan, sosial dan keuangan. Teori konservasi sumber daya menunjukkan bahwa pendapatan rendah mungkin menjadi stresor kronis, meningkatkan tekanan psikologis sebagai akibat dari terbatasnya akses ke sumber daya dan sumber daya akumulasi (Santana et al., 2017)

Menurut (Raphael et al., 2021) faktor yang berpengaruh dalam mengambil sebuah keputusan dalam memilih pengobatan adalah faktor pengalaman dan juga faktor dorongan dari lingkungan sosial. Faktor pengalaman, pengamatan, pembelajaran dari apa yang pernah dialami orang lain sebelumnya sedangkan faktor dari lingkungan sosial berupa motivasi, saran atau pendapat dari lingkungan sosial yang bersifat positif tentang pengobatan yang ada di lingkungan sosial.

Pada penelitian ini factor dukungan keluarga tidak mempunyai pengaruh terhadap pemilihan pengobatan pasien fraktur. Peneliti berasumsi bahwa dorongan pengambilan keputusan dan perilaku ini dilatarbelakangi oleh dorongan dari dalam diri dan pengalaman yang pernah dialami pasien disamping ada juga dorongan dari lingkungan sosial. Perpaduan 
inilah yang membentuk keyakinan partisipan dalam memilih pengobatan tradisional.

Menurut (Bam et al., 2021) ada 2 faktor dasar yang mempengaruhi perilaku seseorang dalam pengambilan keputusan. Faktor tersebut ialah faktor eksternal dan internal. Faktor eksternal merupakan pengaruh dari lingkungan sosial berupa kebudayaan, keluarga dan teman sebaya sedangkan faktor internal merupakan faktor yang dimiliki oleh individu untuk melihat membandingkan dan melakukan pembelajaran dari pengalaman yang pernah dialaminya maupun orang lain yang membantunya dalam memilih tindakan. Hal ini juga sesuai dengan pendapat (JAUHARI, Haris, Utami, 2007), motivasi dan kepercayaan dalam memilih pengobatan konvensional muncul dari informasi dan pengalaman masyarakat maupun pengalaman pribadi tentang keberhasilan yang disediakan pengobatan tradisional.

Penelitian yang dilakukan oleh (Xiao et al., 2020) menyatakan bahwa dukungan sosial secara umum didefinisikan sebagai keyakinan bahwa seseorang diperhatikan, dicintai, dihormati, dan tersedia untuk membantu dan melayani sebagai faktor pelindung dari gangguan emosional. Dukungan sosial terdiri dari berbagai dimensi, termasuk kuantitas dan kualitas dukungan dan dukungan sosial yang dirasakan, yang berasal dari berbagai sumber, termasuk keluarga, teman, rekan kerja dan masyarakat. Peneltian sebelumnya menunjukkan bahwa dukungan sosial yang memuaskan dapat mengurangi terjadinya gangguan stres psikologis sampai batas tertentu, meningkatkan kemampuan pasien yang terluka untuk menangani peristiwa traumatis, dan memberikan perlindungan jangka panjang pada individu melalui mediator, sementara dukungan sosial yang buruk dapat menyebabkan depresi, bunuh diri, gangguan kecemasan, skizofrenia, dan gangguan bipolar. Oleh karena itu, jika keluarga anggota, kerabat, teman, staf medis, dan kelompok social dari semua tingkatan memberikan dukungan emosional, ekonomi dan psikologis yang luas kepada individu yang trauma melalui berbagai cara, maka kemungkinan terjadinya pasien akan merasa diperhatikan dengan baik.

Dari beberapa factor di atas, factor pendidikan memiliki pengaruh yang paling kuat dikarenakan dengan pendidikan yang baik, pasien fraktur akan lebih memilih melakukan pengobatan konvensional dan modern yang berdampak pada pemulihan fraktur yang cepat karena tertangani dengan baik.

\section{KESIMPULAN}

Penelitian ini menemukan beberapa factor yang berpengaruh terhadap pemilihan pengobatan tradisional meliputi factor pendidikan dan ekonomi sedangkan factor pengetahuan dan dukungan kelurga tidak mempunyai pengaruh terhadap pemilihan pengobatan tradisional. Penelitian ini dapat diteruskan dengan meneliti beberapa factor lain yang berkontribusi terhadap pemilihan pengobatan dengan kasus yang berbeda. Dari keempat factor yang terdapat dalam penelitian ini, factor pendidikan yang paling berpengaruh terhadap pasien fraktur dalam memilih pengobatan tradisional.

\section{UCAPAN TERIMAKASIH}

Ucapan terima kasih kami sampaikan kepada semua pihak yang terlibat dalam penelitian ini yaitu pasien fraktur yang bertindak sebagai responden, pimpinan rumah sakit RSUD dr. T.C. Hillers Maumere dan 
siapapun yang terlibat dalam penelitian ini, kami tidak dapat menyebutkannya satu persatu-satu, semoga penelitian ini menjadi bahan masukan dan berkat bagi kita semua

\section{DAFTAR PUSTAKA}

A.Graham Apley; Louis Solomon. (1995). Buku Ajar Ortopedi Dan Fraktur Sistem Apley:( Apley's System Of Orthopaedics And Fractures ). Widya Medika. https://library.unej.ac.id/

Agoes, P. D. H. A. (1996). ANTROPOLOGI KESEHATAN INDONESIA JILID 1 PENGOBATAN TRADISIONAL.

Bam, V., Lomotey, A. Y., Kusi-Amponsah Diji, A., Budu, H. I., BamfoEnnin, D., \& Mireku, G. (2021). Factors influencing decisionmaking to accept elective caesarean section: A descriptive cross-sectional study. Heliyon, 7(8), e07755. https://doi.org/10.1016/j.heliyon. 2021.e07755

Diviani, N., Zanini, C., Jaks, R., Brach, M., Gemperli, A., \& Rubinelli, S. (2020). Information seeking behavior and perceived health literacy of family caregivers of persons living with a chronic condition. The case of spinal cord injury in Switzerland. Patient Education and Counseling, 103(8), 1531-1537. https://doi.org/10.1016/j.pec.202 0.02 .024

Foroudi, P., Gupta, S., Patel, P., Batsakis, G., Vaatanen, J., \& Czinkota, M. (2021). The effect of home country characteristics on the internationalization of EMNEs: The moderating role of knowledge stock. International Business Review, August 2020, 101893.

https://doi.org/10.1016/j.ibusrev. 2021.101893

JAUHARI, Abdul Haris, Dra. Muhana Sofiati Utami, M. (2007). Motivasi dan kepercayaan pasien untuk berobat ke Shinshe :: Studi di Kota Pontianak Propinsi Kalimantan Barat [Gadjah Mada]. http://etd.repository.ugm.ac.id/

Kementerian Kesehatan. (2018). Laporan Hasil Riset Kesehatan Dasar (Riskesdas) 2018.

Lee, G. B. W., Charn, T. C., Chew, Z. H., \& Ng, T. P. (2004). Complementary and alternative medicine use in patients with chronic diseases in primary care is associated with perceived quality of care and cultural beliefs. Family Practice, 21(6), 654-660. https://doi.org/10.1093/fampra/c mh613

Liang, N., Feng, X., Liu, J., \& Cao, H. (2018). The effect of traditional Chinese medicine education programs on people's subhealth status: A systematic review of clinical studies. European Journal of Integrative Medicine, 22(July), 69-75. https://doi.org/10.1016/j.eujim.20 18.07.009

Mattarneh, S. (2015). A study of factors causing cost overruns in Jordanian construction industry.

Peprah, P., Mawuli Abalo, E., Nyonyo, J., Okwei, R., Agyemang-Duah, W., \& Amankwaa, G. (2018). Pregnant women's perception 
and attitudes toward modern and traditional midwives and the perceptional impact on health seeking behaviour and status in rural Ghana. International Journal of Africa Nursing Sciences, 8(March), 66-74. https://doi.org/10.1016/j.ijans.20 18.03.003

R. Bassey, Aquaisua N. Aquaisua, +2 authors Enobong I. Bassey. (2009). The Practice Of Traditional Bone Setting In The South- South Region Of Nigeria. The Internet Journal of Alternative Medicine. https://doi.org/DOI:10.5580/566

Raphael, D. B., Russell, N. S., Winkens, B., Immink, J. M., Westhoff, P. G., Stenfert Kroese, M. C., Stam, M. R., Bijker, N., van Gestel, C. M. J., van der Weijden, T., \& Boersma, L. J. (2021). A patient decision aid for breast cancer patients deciding on their radiation treatment, no change in decisional conflict but better informed choices. Technical Innovations \& Patient Support in Radiation Oncology, 20(August), 1-9.

https://doi.org/10.1016/j.tipsro.20 21.08.002

RSUD dr. T.C. Hillers. (2020). Data pasien Fraktur Rawat Inap.

Santana, M. R. M., Zatti, C., Spader, M. L., Malgarim, B. G., Salle, E., Piltcher, R., Ceresér, K. M. M., Bastos, A. G., \& Freitas, L. H. (2017). Acute stress disorder and defense mechanisms: A study of physical trauma patients admitted to an emergency hospital. Trends in Psychiatry and Psychotherapy,
39(4), 247-256. https://doi.org/10.1590/22376089-2016-0071

Susi Hanifah Kurnia. (2019). FAKTORFAKTOR YANG MELATARBELAKANGI PASIEN PATAH TULANG BEROBAT KE PENGOBATAN TRADISIONAL AHLI TULANG DI SUMEDANG ((000116962)).

https://repository.unpad.ac.id/fro ntdoor/index/index/year/0000/do cId/116962

Worku, N., Tewelde, T., Abdissa, B., \& Merga, H. (2019). Preference of Traditional Bone Setting and associated factors among trauma patients with fracture at Black Lion Hospital in Addis Ababa , Ethiopia: institution based cross sectional study. BMC Research Notes, $10-15$. https://doi.org/10.1186/s13104019-4643-z

Xiao, Q., Ran, J., Lu, W., Wan, R., Dong, L., \& Dai, Z. (2020). Analysis of the point prevalence and influencing factors of acute stress disorder in elderly patients with osteoporotic fractures. Neuropsychiatric Disease and Treatment, 16, 2795-2804. https://doi.org/10.2147/NDT.S26 5144 